\title{
Premature feather loss among common tern chicks in Ontario: the return of an enigmatic developmental anomaly
}

Jennifer M. Arnold, Donald J. Tyerman, Doug Crump, Kim L. Williams, Stephen A. Oswald

In July 2014, we observed premature feather loss (PFL) among non-sibling, common tern Sterna hirundo chicks between 2 and 4 weeks of age at Gull Island in northern Lake Ontario, Canada. Rarely observed in wild birds, to our knowledge PFL has not been recorded in terns since 1974, despite the subsequent banding of hundreds of thousands of tern chicks across North America alone. The prevalence, $5 \%$ of chicks (9/167), and extent of feather loss we report is more extreme than in previous reports for common terns but was not accompanied by other aberrant developmental or physical deformities. Complete feather loss from all body areas (wing, tail, head and body) occurred over a period of a few days but all affected chicks appeared vigorous and quickly began to grow replacement feathers. All but one chick (recovered dead and submitted for post-mortem) most likely fledged 10-20 days after normal fledging age. We found no evidence of feather dystrophy, concurrent developmental abnormalities or nutritional shortfall among affected chicks. Thus, the PFL we observed among common terns in 2014 was largely of unknown origin. There was striking temporal association between the onset of PFL and persistent strong southwesterly winds that caused extensive mixing of near-shore surface water with cool, deep lake waters. One hypothesis is that PFL may have been caused by unidentified pathogens or toxins welling up from these deep waters along the shoreline but current data are insufficient to test this. PFL was not observed among common terns at Gull Island in 2015, although we did observe similar feather loss in a herring gull Larus argentatus chick in that year. Comparison with sporadic records of PFL in other seabirds suggests that PFL may be a rare, but non-specific response to a range of potential stressors. PFL is now known for gulls, penguins and terns. 
1 Premature feather loss among common tern chicks in Ontario: the return of an enigmatic

2 developmental anomaly

3 JENNIFER M. ARNOLD ${ }^{1 *}$, DONALD J. TYERMAN ${ }^{2}$, DOUG CRUMP $^{3}$, KIM WILLIAMS $^{3}$ \&

4 STEPHEN A. OSWALD ${ }^{1}$

$5 \quad{ }^{1}$ Division of Science, The Pennsylvania State University, Berks Campus, 2080 Tulpehocken

6 Road, Reading, PA 19610, USA.

72 Presqu'ile Provincial Park, Ontario Parks, 328 Presqu'ile Parkway, R.R. \#4 Brighton, Ontario,

$8 \mathrm{~K} 0 \mathrm{~K} 1 \mathrm{H} 0$, Canada.

$9{ }^{3}$ National Wildlife Research Centre, Environment Canada, 1125 Colonel By Drive, Ottawa,

10 Ontario, K1A 0H3, Canada.

12 Short Title: Premature feather loss in terns

13 KEYWORDS: avian virus, algal toxins, contaminants, feather loss, Great Lakes, induced moult,

14 nutritional stress, pathogens, premature moult

15

16 *Corresponding author:

17 Jennifer M. Arnold

18 Division of Science,

19 The Pennsylvania State University, Berks Campus,

202080 Tulpehocken Road,

21 Reading, PA 19610, USA

22 Tel: +1-610-396-6002

23 E-mail: jma25@psu.edu 


\section{Abstract}

25 In July 2014, we observed premature feather loss (PFL) among non-sibling, common tern Sterna

26 hirundo chicks between 2 and 4 weeks of age at Gull Island in northern Lake Ontario, Canada.

27 Rarely observed in wild birds, to our knowledge PFL has not been recorded in terns since 1974,

28 despite the subsequent banding of hundreds of thousands of tern chicks across North America

29 alone. The prevalence, $5 \%$ of chicks (9/167), and extent of feather loss we report is more

30 extreme than in previous reports for common terns but was not accompanied by other aberrant

31 developmental or physical deformities. Complete feather loss from all body areas (wing, tail,

32 head and body) occurred over a period of a few days but all affected chicks appeared vigorous

33 and quickly began to grow replacement feathers. All but one chick (recovered dead and

34 submitted for post-mortem) most likely fledged 10-20 days after normal fledging age.

35 We found no evidence of feather dystrophy, concurrent developmental abnormalities or nutritional shortfall among affected chicks. Thus, the PFL we observed among common terns in 2014 was largely of unknown origin. There was striking temporal association between the onset of PFL and persistent strong southwesterly winds that caused extensive mixing of near-shore surface water with cool, deep lake waters. One hypothesis is that PFL may have been caused by unidentified pathogens or toxins welling up from these deep waters along the shoreline but current data are insufficient to test this.

PFL was not observed among common terns at Gull Island in 2015, although we did observe similar feather loss in a herring gull Larus argentatus chick in that year. Comparison with sporadic range of potential stressors. PFL is now known for gulls, penguins and terns. 


\section{Introduction}

In common terns, Sterna hirundo, the first feather molt occurs between four and seven months after fledging (Nisbet 2002). Thus, feather loss for chicks prior to fledging is not part of normal development (Wails et al. 2014). In July 2014, we observed premature feather loss (PFL) among pre-fledging common tern chicks at Gull Island in northern Lake Ontario, Canada. This condition, whereby developing chicks lose their wing, tail, head and body feathers, has rarely been documented in wild birds. To our knowledge, PFL has only been reported for terns in coastal, eastern North America and at Indian Ocean breeding islands between 1970 and 1974 (Gochfeld 1971, 1975, Hays and Risebrough 1972, Feare 1974). At that time, it was cautiously associated with contaminant burdens, chiefly mercury and polychlorinated biphenyls (PCBs) (Hays and Risebrough 1972, Gochfeld 1980), and pathogenic organisms and their toxins (Bourne et al. 1977). However, researchers were unable to rule out the possibility of other stressors (such as trauma, cancers, allergens, infections, and genetic factors) (Gochfeld 1971).

In general, feather loss (aside from molt) can be caused by starvation, nutritional deficiencies, pecking, shock molt, and Psittacine Beak and Feather Disease (Spearman 1980, Hughes 1985, Leeson and Walsh 2004, Møller et al. 2006). Although commonly reported in poultry (Hughes 1985, Leeson and Walsh 2004), feather loss is rarely reported in wild birds except for some pathogenic infections (e.g. in psittacines; Ha et al. 2007; but see Table 1), and occasional observations from pecking during territorial disputes in colonial birds (e.g. Nisbet et al 1978). In North America, PFL in common terns was reported locally in the vicinity of Long Island, New York, as well as a few locations in coastal Connecticut and Massachusetts, between 1970 and 1974 (Hays and Risebrough 1972, Nisbet 1972, Gochfeld 1980). However, to the best of our knowledge, and despite the banding of over 850,000 common terns in North America since then (Bystrack pers. comm.), no further cases have been reported anywhere.

Our detection of PFL in common terns is just one of an increasing number of reports of this condition in a range of wild bird species (Table 1). Given that this condition is highly visible, the recent escalation in its detection worldwide may indicate changing health risks for birds and other wildlife. Here, we describe the chronology and progression of PFL at Gull Island, Ontario in 2014 and review associated evidence to narrow down potential causes of this aberrant development. We aim to increase awareness of this phenomenon among ornithologists and the wider scientific community to ensure timely reporting of future occurrences that may lead to a better understanding of the underlying causes of PFL.

\section{Materials \& Methods}

Since 2008, we have studied the reproductive biology of common terns annually at Gull Island, Presqu'ile Provincial Park, ON, Canada $\left(43^{\circ} 59^{\prime} \mathrm{N}, 77^{\circ} 45^{\prime} \mathrm{W}\right)$ under appropriate authorizations: Canadian Wildlife Service Permits CA 0218, CA 0234, CA 0242, CA 0267, CA 0308; Environment Canada Bird Banding Permits $10431 \mathrm{~V}$ and $10431 \mathrm{~W}$; Ontario Parks Authorizations to Conduct Research in a Provincial Park 2008 - 2015 inclusive; and Institutional 
Animal Care and Use Committee (IACUC) of Pennsylvania State University approved protocols 45332, 36295, 28103. Following standard protocols (Arnold et al. 2016), each year nearly all chicks were banded within 1-2 d of hatching and chicks from all study nests $(\sim 80-130)$ were recaptured and weighed regularly (every $\sim 1-4 \mathrm{~d}$ ) from hatching until fledging. Number of chicks banded in each year varied between 108 and 297 depending on the intensity of nest predation by night-herons and gulls (unrelated to our monitoring). In 2014, chicks were recaptured every $\sim 1-4$ $\mathrm{d}$ until 24 July (when the majority of chicks were $28 \mathrm{~d}$ or older; median fledging age is $24-25 \mathrm{~d}$ at this colony) and then weekly until 20 August.

On discovery of premature feather loss (PFL) in multiple individual chicks (that previously exhibited normal feathering) at Gull Island, we took a range of photographs (head, tail, wing, body) and also measured wing length (maximum wing chord) and tail length (maximum length of longest outer tail feather) at each subsequent recapture using a $300 \mathrm{~mm}$ wing rule. The same measurements were made for a sample of 7 normally developing tern chicks during this time period; mass measurements were available from 159 normally developing chicks. The carcass of one subsequently dead PFL chick was sent to D. Campbell, of the Canadian Wildlife Health Cooperative, Ontario Veterinary College for post-mortem.

Repeated mass measurements from eight chicks that exhibited PFL were used to construct a composite growth curve for comparison to larger samples of normally developing chicks. Fledging masses were estimated for 29 normally-feathered chicks as their mass on the date of last recapture prior to fledging (median fledging age $=24-25 \mathrm{~d}$ ) and compared to the masses of 7 PFL chicks at their last recapture (age range: $20-41 \mathrm{~d}$, median $=27-28 \mathrm{~d}$ ) using a Student's $t$-test. Median wing and tail growth rates (slopes of measurements within individuals) for chicks exhibiting PFL and normally-feathered chicks were compared using Mann Whitney U-tests. For these analyses, only chicks with similar hatch dates and and multiple measurements between ages $20 \mathrm{~d}$ to $36 \mathrm{~d}$ were included in analyses (6 PFL chicks and 3 normally-feathered chicks). For each PFL chick, we used current wing length and the calculated rate of daily wing growth (slope of maximum chord) on the last day it was measured (range 16-24 ${ }^{\text {th }} \mathrm{July}$ ) to projected its fledging date (the date at which wing lengths would have equaled $180 \mathrm{~mm}$; the smallest wing length for a normal, fledged common tern chick in 2014). The assumption of a constant growth rate between $\sim 10 \mathrm{~d}$ of age and fledging is supported by data on wing growth in this species (LeCroy \& Collins 1972).

Local, hourly weather data from the Trenton, ON, weather station $\left(44^{\circ} 7^{\prime} \mathrm{N}, 77^{\circ} 32^{\prime} \mathrm{W} ; 21 \mathrm{~km}\right.$ to the northwest) were downloaded from Environment Canada (http://climate.weather.gc.ca/). From these we calculated daily ( $24 \mathrm{~h}$ ) means from 1 May to 31 July 2014 for air temperature, relative humidity, wind speed, wind direction, visibility and standard atmospheric pressure, and also minimum nighttime temperatures and maximum daytime air temperatures. Lake surface temperature was retrieved from Environment Canada (http://weather.gc.ca) for the nearest, near-

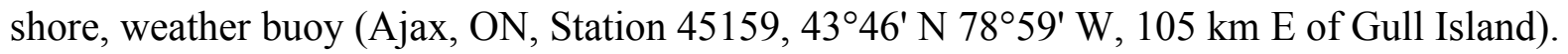


123 For comparative purposes, the same data were also extracted for all years in which data coverage

124

125

126

127

128

129

130

131

132

133

134

135

136

137

138

139

140

141

142

143

144

145

146

147

148

149

150

151

152

153

154

155

156

157

158

159

was sufficiently comprehensive (2009-2015).

Analyses were conducted in R (R Core team 2015). All means are reported with $\pm 1 \mathrm{SD}$, all medians with quartiles [upper, lower].

\section{Results}

Premature feather loss (PFL) was first discovered in two non-sibling, common tern chicks at Gull Island on 5 July, 2014. Initial symptoms that we recorded at this time were missing feathers on the head and body, similar in extent to that sometimes resulting from territorial aggression by neighboring adults or chicks (but more extreme and without the associated laceration, bruising or hemorrhaging). However, by 8 July these two chicks had lost down, primaries and most feathers from all areas of the head, body, tail and wings, and in one chick, pin feathers were already growing back in places (Fig 1). On this same day, two other chicks exhibited PFL symptoms for the first time. Three chicks were found with PFL between 9 and 11 July and another one chick exhibited PFL on 24 July. We also discovered an unbanded, medium-sized chick (estimated as 13-15 d of age) exhibiting PFL on 15 Aug (which is excluded from the analyses that follow). Thus a total of nine chicks were found that exhibited PFL out of the 167 handled and banded (5.3 \%) at Gull Island in 2014. Although all eight of the banded PFL chicks were from either 2- or 3chick broods, none had siblings that showed signs of PFL.

No evidence of feather dystrophy was found in the dead PFL chick sent for post-mortem analysis, reducing the likelihood that this PFL resulted from a viral infection (such as that from Circovirus and Papovavirus) (D. Campbell, pers. comm.). It also showed no obvious signs of infection or abnormality in heart, lung, liver or kidney tissues (D. Campbell, pers. comm.). There was a high level of cellularity in the pulp of the feathers, but the significance of this is unclear (D. Campbell, pers. comm.).

The mean age of chicks when first exhibiting PFL was $18( \pm 3.7) \mathrm{d}$ (range: $15-26 \mathrm{~d})$. Visual comparison between normal plumage development and that of chicks exhibiting PFL is provided in Fig 1. Although growth in mass for chicks exhibiting PFL appeared normal initially, from approximately $10 \mathrm{~d}$ of age until normal fledging age ( $25 \mathrm{~d})$ masses were generally lower than the colony average (Fig 2). Although median rates of both wing and tail growth were slightly higher for PFL chicks than normally-feathered chicks at similar ages, these differences were not statistically significant (wing: $\mathrm{PFL}=5.5[4.3,6.2] \mathrm{mm} / \mathrm{d}(\mathrm{n}=6)$, Normal $=4.0[2.8,5.3] \mathrm{mm} / \mathrm{d}$ $(\mathrm{n}=3), \mathrm{W}=5, \mathrm{P}=0.38$; tail: $\mathrm{PFL}=3.8[2.9,4.9] \mathrm{mm} / \mathrm{d}(\mathrm{n}=6)$, Normal $=3.3[2.2,3.5] \mathrm{mm} / \mathrm{d}(\mathrm{n}$ $=3), \mathrm{W}=3, \mathrm{P}=0.17)$.

The seven surviving banded chicks that exhibited PFL in July were last seen between 21 and 42 d of age (mean: $29.1 \pm 6.5 \mathrm{~d}$ ). Mean body mass at their last measurement date (between $16^{\text {th }}$ and $2^{4 \text { th }}$ July) was $119.3( \pm 9.2) \mathrm{g}$, effectively identical to the colony average $(118.3 \pm 8.1 \mathrm{~g}, \mathrm{n}=29$; $t_{34}=0.3, \mathrm{P}=0.77$ ) for normally-feathered birds of similar age (the normal fledging age median: 
160

161

162

163

164

165

166

167

168

169

170

171

172

173

174

175

176

177

178

179

180

181

182

183

184

185

186

187

188

189

190

191

192

193

194

195

196

197

24-25 d). Mean wing length of the PFL chicks was $125( \pm 23) \mathrm{mm}$ during this same time period (compared to a minimum of $180 \mathrm{~mm}$ for a normally-feathered, fledged chick in 2014). The earliest and latest projected fledging dates for the PFL chicks were 26 July and 20 Aug (mean: 2 Aug $\pm 9 \mathrm{~d}$ ), respectively. During a visit to the colony on 11 Aug, we estimated there to be between 15 and 25 active common tern broods (based on counts of persistently dive-bombing adults) of the 107 total nests that were initiated in 2014 .

The period in which PFL was first detected in common tern chicks (and three days immediately prior to it; 2 - 10 July) was characterized by plummeting near-shore, lake surface temperatures (Fig 3a) and falling air temperatures (Fig 3b) as well as stronger southwesterly winds (Fig 3c \& d) and rising atmospheric pressure (not shown). Minimum nighttime temperatures and maximum daytime temperatures were highly correlated with mean air temperature $\left(\mathrm{r}_{89}=0.82\right.$ and $\mathrm{r}_{90}=$ 0.99 , respectively) and showed the same response (not shown). However, there were no obvious changes in relative humidity or visibility at this time (also not shown). The coincidence of these weather conditions with the chick-rearing schedule of common terns was unusual: across the seven years for which data were available, only one other similar event (July 20 th 2013 ) was detected, although in this case lake surface temperature change was less extreme $\left(8 \mathrm{C}^{\circ} \mathrm{vs} .13 \mathrm{C}^{\circ}\right)$ and was primarily a result of one, strong, north-westerly storm rather than persistent southwesterlies.

\section{Discussion}

The premature feather loss (PFL) that we observed in common tern chicks at Gull Island in 2014 is similar in two ways to that described by researchers working on the Atlantic coast of North America in the early 1970s. Firstly, we only observed it in chicks when they were between 2 and 4 weeks of age, the same age as noted by Hays \& Risebrough (1972) and similar to Gochfeld (1971) [3-5 weeks], although in this latter case PFL was mostly restricted to chicks closer to normal fledging age (Gochfeld 1971, Gochfeld pers. comm.). Secondly, in all reported cases, a proportion of chicks that shed feathers grew replacements and appeared otherwise healthy and vigorous (Gochfeld 1971, Hays and Risebrough 1972). This was true of nearly all affected chicks at Gull Island in 2014. In fact, our PFL chicks, although they consequently had shorter wings and tails than normally-feathered chicks of the same age (Fig 1), showed no reduction in feather growth rates following feather loss. This is unsurprising, since feather growth appears highly conserved (e.g. under conditions of nutritional stress; Bize et al. 2006, Lyons and Roby 2011).

There are a few interesting differences between the PFL we observed and that previously documented both in terns and other waterbirds (Table 1). Complete feather loss (Fig 1) is the extreme among terns in previous reports, as some birds only lost primaries and/or tail feathers (Gochfeld 1971, 1975, Hays and Risebrough 1972, Feare 1974, Bourne et al. 1977). Similar complete feather loss and regrowth has been observed in other species, e.g. greater black-backed gulls (Larus marinus) (Roy et al. 1986), and African (Spheniscus demersus) and Magellanic ( $S$. magellanicus) penguins (Kane et al. 2010). The incidence of PFL at our colony in 2014 was 5\% 
198 (9/167) of all chicks, higher than that reported previously for common terns $(0.5-1.1 \%$; Hays

199

200

201

202

203

204

205

206

207

208

209

210

211

212

213

214

215

216

217

218

219

220

221

222

223

224

225

226

227

228

229

230

231

232

233

234

235

236

and Risebrough 1972, Gochfeld 1975), although similar rates have been noted for other terns and gulls (Feare 1974, Roy et al. 1986) and even higher incidences in rehabilitated penguins (Kane et al. 2010). Unlike all other reports for terns, we did not observe concurrent developmental abnormalities (e.g. crossed-bills, aberrant limb development; Feare 1974, Gochfeld 1975, Bourne et al. 1977) in PFL chicks or any other common tern chicks at our site. Lack of concurrent abnormalities is, however, consistent with historical records for gulls (Roy et al. 1986) and contemporary reports among penguins (Kane et al. 2010, Barbosa et al. 2015, Grimaldi et al. 2015). Colony-wide hatching success also did not appear any different from in previous years (Arnold \& Oswald unpublished data), suggesting an absence of gross embryonic deformity (such situations were previously linked with PFL; Hays and Risebrough 1972). Interestingly, previous studies in the lower Great Lakes between 1971 and 1973 detected a high prevalence of deformity among common tern chicks (including one chick at Presqu'ile Provincial Park) but no cases of PFL (Gilbertson et al. 1976).

While growth rates of wings and tails of common tern chicks recovering from PFL in 2014 appeared normal, PFL chicks had lower masses than normally-feathered chicks between approximately $10 \mathrm{~d}$ of age and normal fledging age ( $\sim 25 \mathrm{~d})$. Although some of this may be directly due to the absence of plumage, the maximum differences we observed $(\sim 30 \mathrm{~g}$ on average at $18 \mathrm{~d}$ of age; Fig 2) likely exceeded the weight of lost plumage (5-9 g, based on estimates of plumage mass for similar species: 5-7\% of body mass; Braune and Gaskin 1987, Marks 1993). As chicks recovering from PFL appeared vigorous and highly aggressive in some cases, this is unlikely to result from a competitive disadvantage during provisioning events (e.g. Oswald et al. 2012) but instead a preferential channeling of energy to feather regrowth. Such a relationship between PFL and growth has been previously documented for penguins (Kane et al. 2010) but not terns (Gochfeld 1971). PFL did not appear to affect the known tendency for tern chicks to overshoot adult mass and subsequently lose mass at this site, as the proportion of PFL chicks exhibiting this growth trajectory (25\% [2/8 chicks]) was similar to that previously reported (34$38 \%$, Arnold et al. 2016).

Other reports of PFL in terns have been for chicks late in the breeding season (Gochfeld 1971) but at Gull Island in 2014, PFL was first observed in early July (median hatching date across all chicks in 2014 was 21 June) and an active colony persisted well into mid-August. There was a striking association between the timing of the onset of PFL at Gull Island in 2014 and strong, southwesterly winds, falling air temperatures, and plummeting (up to $13 \mathrm{C}^{\circ}$ ) near-shore, lake surface temperatures (daily means shown in Fig 3): conditions characteristic of mixing of cold, deep lake waters with warmer surface waters. The extent of lake-surface temperature change observed in 2014 is rare, comparable to only one other weather event within the last seven years at a similar stage in the common tern breeding cycle (July 2013). However, this 2013 weather event was driven by strong, northwesterly winds and showed less extreme temperature change; presumably more northerly winds gave a lower potential for mixing of deep lake waters with 
237

238

239

240

241

242

243

244

245

246

247

248

249

250

251

252

253

254

255

256

257

258

259

260

261

262

263

264

265

266

267

268

269

270

271

shallow coastal waters of the northern lake shore (where Gull Island is located). There was also no evidence of PFL among developing chicks in 2013. Therefore, one hypothesis is that the PFL we observed in 2014 may have been caused by unidentified pathogens or toxins welling up from deep lake waters but current data are insufficient to test this.

Exposure to as-yet-unknown toxins or pathogens seems the most likely current explanation of PFL in common tern chicks at Gull Island. Most affected chicks were between 1-2 weeks of age during the time period when PFL was first observed (5 July), although one PFL chick was hatched at this time and the egg of another chick that developed PFL in August was laid at this time. We favor exposure to unknown toxins or pathogenic organisms as the causal mechanism.

Comparison with sporadic records of PFL in other birds (Table 1) suggests that PFL may be a rare, but non-specific response to a range of potential stressors, including environmental contaminants, viral and bacterial infections, tick-borne disease or nutritional deficiency. Given that PFL is very obvious in affected chicks (Fig 1) but is seldom reported despite the great number of studies that should detect it, the low incidence of reporting likely represents a rare condition rather than simply underreporting (Gochfeld 1971, Roy et al. 1986, Barbosa et al. 2015, Grimaldi et al. 2015). In 2015, we found no evidence of PFL in common terns despite similar nesting numbers and research protocols, but we did observe a single herring gull ( $L$. argentatus) chick exhibiting premature feather loss (Arnold \& Oswald unpubl. obs.). Thus, the recent records of PFL in penguins (including adults; Grimaldi et al. 2015), gull and tern chicks may perhaps indicate widespread environmental changes that could lead to health risks for birds and other wildlife, especially if pathogenic organisms are responsible (Bourne et al. 1977).

\section{Acknowledgements}

We thank S. Smith and our field assistants from 2014: M. Bush, G. Care, S. Conway, J. Kenna, P. McFarland Jr., L. Post, K. Ringler, and J. Smith, as well as J. Edwards (2015 assistant). We are greatly indebted to the following for feedback on earlier drafts of the manuscript and/or our observation of PFL: I.C.T. Nisbet, M. Gochfeld, C.M. Custer, I. Barker, R. Shirley, O.J. Kane, T. Custer, D. Campbell, R.D. Morris, J.M. Levengood, J. Farquhar, C. Grooms, L. Harper, D.V. Weseloh, F.J. Cuthbert, C. Adams, M. LaBarr, and C.N. Wails.

\section{References}

Arnold, J. M., Nisbet, I. C. T. and Oswald, S. A. 2016. Energetic constraint of non-monotonic mass change during offspring growth: a general hypothesis and application of a new tool. J. Anim. Ecol. 85: 476-486.

Barbosa, A., Colominas-Ciuró, R., Coria, N., Centurión, M., Sandler, R., Negri, A. and Santos, M. 2015. First record of feather-loss disorder in Antarctic penguins. - Antarct. Sci. 27: 6970. 
272

273

274

275

276

277

278

279

280

281

282

283

284

285

286

287

288

289

290

291

292

293

294

295

296

297

298

299

300

301

302

303

304

Bize, P., Metcalfe, N. B. and Roulin, A. 2006. Catch-up growth strategies differ between body structures: Interactions between age and structure-specific growth in wild nestling Alpine Swifts. - Funct. Ecol. 20: 857-864.

Bourne, W. R. P., Bogan, J. A. and Bullock, D. 1977. Abnormal terns, sick sea and shore birds, organochlorines and arboviruses in the Indian Ocean. - Mar. Pollut. Bull. 8: 154-158.

Braune, B. M. and Gaskin, D. E. 1987. A mercury budget for the Bonaparte's gull during autumn moult. - Ornis Scand. 18: 244-250.

Burger, J. and Gochfeld, M. 2004. Marine birds as sentinels of environmental pollution. Ecohealth 1: 263-274.

Feare, C. J. 1974. Desertion and abnormal development in a colony of sooty terns Sterna fuscata infested by virus-infected ticks. - Ibis (Lond. 1859). 118: 112-115.

Gilbertson, M., Morris, R. D. and Hunter, R. A. 1976. Abnormal chicks and PCB residue levels in eggs of colonial birds on the Lower Great Lakes (1971-1973). - Auk 93: 434-442.

Gochfeld, M. 1971. Premature feather loss - a "new disease" of Common Terns on Long Island, New York. - Kingbird 21: 206-211.

Gochfeld, M. 1975. Developmental defects in common terns of western Long Island, New York. - Auk 92: 58-65.

Gochfeld, M. 1980. Tissue distribution of mercury in normal and abnormal young Common Terns. - Mar. Pollut. Bull. 11: 362-377.

Grimaldi, W. W., Hall, R. J., White, D. D., Wang, J., Massaro, M. and Tompkins, D. M. 2015. First report of a feather loss condition in Adelie penguins (Pygoscelis adeliae) on Ross Island, Antarctica, and a preliminary investigation of its causes. - Emu 115: 185-189.

Ha, H. J., Anderson, I. L., Alley, M. R., Springett, B. P. and Gartrell, B. D. 2007. The prevalence of beak and feather disease virus infection in wild populations of parrots and cockatoos in New Zealand. - N. Z. Vet. J. 55: 235-238.

Hays, H. and Risebrough, R. W. 1972. Pollutant concentrations in abnormal young terns from Long Island Sound. - Auk 89: 19-35.

Hughes, B. 1985. Feather loss — how does it occur? - Proc. 2nd Eur. Poult. Welf. Symp.: 178188.

Kane, O. J., Smith, J. R., Dee Boersma, P., Parsons, N. J., Strauss, V., Garcia-Borboroglu, P. and Villanueva, C. 2010. Feather-Loss disorder in African and magellanic penguins. Waterbirds 33: 415-421.

LeCroy, M. and Collins, C. T. 1972. Growth and survival of roseate and common tern chicks. - 
Auk 89: 595-611.

Leeson, S. and Walsh, T. 2004. Feathering in commercial poultry - II. Factors influencing feather growth and feather loss. - Worlds Poult. Sci. J. 60: 52-63.

Lyons, D. E. and Roby, D. D. 2011. Validating growth and development of a seabird as an indicator of food availability: captive-reared Caspian Tern chicks fed ad libitum and restricted diets. - J. F. Ornithol. 82: 88-100.

Marks, J. S. 1993. Molt of bristle-thighed curlews in the Northwestern Hawaiian Islands. - Auk 110: 573-587.

Møller, A. P., Nielsen, J. T. and Erritzoe, J. 2006. Losing the last feather: feather loss as an antipredator adaptation in birds. - Behav. Ecol. 17: 1046-1056.

Nisbet, I. C. T. 1972. Disaster year for terns. - Man Nat. December: 16-21.

Nisbet, I. C. T. 2002. Common tern (Sterna hirundo). - In: Poole, A. and Gill, F. (eds), The Birds of North America, Inc., in press.

Oswald, S., Arnold, J., Hatch, J. and Nisbet, I. 2012. Piracy at the nest: Factors driving kleptoparasitic behaviour of Common Tern Sterna hirundo chicks. - Acta Ornithol. 47: 95100.

R Core team 2015. R: A language and environment for statistical computing. v3.13 Available at: http://www.r-project.org/.

Roy, N. A., Threlfall, W. and Wheeler, T. A. 1986. Feather loss of unknown etiology in a gull colony in Newfoundland, Canada. - J. Wildl. Dis. 22: 591-594.

Spearman, R. 1980. The avian skin in relation to surface ecology. - Proc. R. Soc. Edinburgh Sect. B. Biol. Sci. 79: 57-74.

van Heezik, Y. and Seddon, P. J. 1992. Starvation and delayed plumage development in Jackass Penguin chicks. - Ostrich 63: 129-131.

Wails, C. N., Oswald, S. A. and Arnold, J. M. 2014. Are morphometrics sufficient for estimating age of pre-fledging birds in the field? A test using common terns (Sterna hirundo). - PLoS One 9: e111987. 


\section{Table $\mathbf{1}$ (on next page)}

Reports of premature feather loss in waterbirds.

Table 1. Reports of premature feather loss in wild populations of waterbirds. In all reports, feather-loss in some individuals studied was extensive. 
Table 1. Reports of premature feather loss (PFL) in waterbirds. In all reports, feather-loss in some individuals studied was extensive.

\begin{tabular}{|c|c|c|c|c|}
\hline Species & Location & Years & Explanation & Source \\
\hline $\begin{array}{l}\text { Common tern } \\
\text { (Sterna hirundo) }\end{array}$ & Long Island, NY & 1970-1974 & $\begin{array}{l}\text { Proposed link to contaminants } \\
\text { (e.g. PCBs, mercury) }\end{array}$ & $\begin{array}{c}\text { Gochfeld 1971, 1975; } \\
\text { Hays \& Risebrough } \\
1972\end{array}$ \\
\hline $\begin{array}{l}\text { Sooty tern } \\
\text { (Sterna fuscata) }\end{array}$ & Seychelles & 1973 & Tick-borne soldado-virus & Feare 1974 \\
\hline $\begin{array}{l}\text { Greater Black-backed gull } \\
\text { (Larus marinus) }\end{array}$ & $\begin{array}{l}\text { Witless Bay, } \\
\text { Newfoundland }\end{array}$ & 1984 & Unknown cause & Roy et al. 1986 \\
\hline $\begin{array}{l}\text { Herring gull } \\
\text { (Larus argentatus) }\end{array}$ & $\begin{array}{l}\text { Witless Bay, } \\
\text { Newfoundland }\end{array}$ & 1984 & Unknown cause & Roy et al. 1986 \\
\hline $\begin{array}{l}\text { African penguin } \\
\text { (Spheniscus demersus) }\end{array}$ & South Africa & 1989 & Malnutrition & $\begin{array}{l}\text { van Heezik and Seddon } \\
1992\end{array}$ \\
\hline $\begin{array}{l}\text { Emperor penguin } \\
\text { (Aptenodytes forsteri) }\end{array}$ & $\begin{array}{l}\text { Cape Washington, } \\
\text { Antarctica }\end{array}$ & mid-1990s & Unknown cause & $\begin{array}{l}\text { reported in Varsani et al } \\
2014\end{array}$ \\
\hline $\begin{array}{l}\text { Magellanic penguin } \\
\text { (Spheniscus magellanicus) }\end{array}$ & Argentina & $2007-2008$ & Unknown cause & Kane et al. 2010 \\
\hline $\begin{array}{l}\text { African penguin } \\
\text { (Spheniscus demersus) }\end{array}$ & South Africa & 2008 & Unknown cause & Kane et al. 2010 \\
\hline $\begin{array}{l}\text { Adelie penguin } \\
\text { (Pygoscelis adeliae) }\end{array}$ & $\begin{array}{l}\text { Cape Crozier, } \\
\text { Antarctica }\end{array}$ & 2011 & Unknown cause & $\begin{array}{l}\text { reported in Varsani et al } \\
2014\end{array}$ \\
\hline $\begin{array}{l}\text { Common tern } \\
\text { (Sterna hirundo) }\end{array}$ & $\begin{array}{l}\text { Gull Island, Lake } \\
\text { Ontario }\end{array}$ & 2014 & $\begin{array}{l}\text { Unknown cause, possible link to } \\
\text { environmental conditions }\end{array}$ & This study \\
\hline $\begin{array}{l}\text { Adelie penguin } \\
\text { (Pygoscelis adeliae) }\end{array}$ & $\begin{array}{l}\text { Ross Is. \& Antarctic } \\
\text { Peninsula }\end{array}$ & $2011-2015$ & $\begin{array}{c}\text { Proposed avian virus } \\
\text { (polyomavirus, novel astrovirus) }\end{array}$ & $\begin{array}{l}\text { Barbosa et al. } 2015 \text {; } \\
\text { Grimaldi et al. } 2015\end{array}$ \\
\hline $\begin{array}{l}\text { Herring gull } \\
\text { (Larus marinus) }\end{array}$ & $\begin{array}{l}\text { Gull Island, Lake } \\
\text { Ontario }\end{array}$ & 2015 & Unknown cause & $\begin{array}{l}\text { Arnold \& Oswald } \\
\text { unpubl. obs. }\end{array}$ \\
\hline
\end{tabular}




\section{1}

Plumage characteristics resulting from of premature feather loss (PFL) in common tern chicks at Gull Island in 2014.

Figure 1. Plumage characteristics resulting from of premature feather loss (PFL) in common tern chicks at Gull Island in 2014 (left hand panel) versus normal development (right hand panel; photo with white background taken from Common Tern Aging Guide: Wails et al. 2014). In each case, whole body $(a, b)$, wing $(c, d)$ and tail $(e, f)$ are shown (pictures taken between 9 and 18 July). Chicks shown are between 21 and $27 \mathrm{~d}$ of age (fledging usually occurs between 21-29 days; Nisbet 2002). 

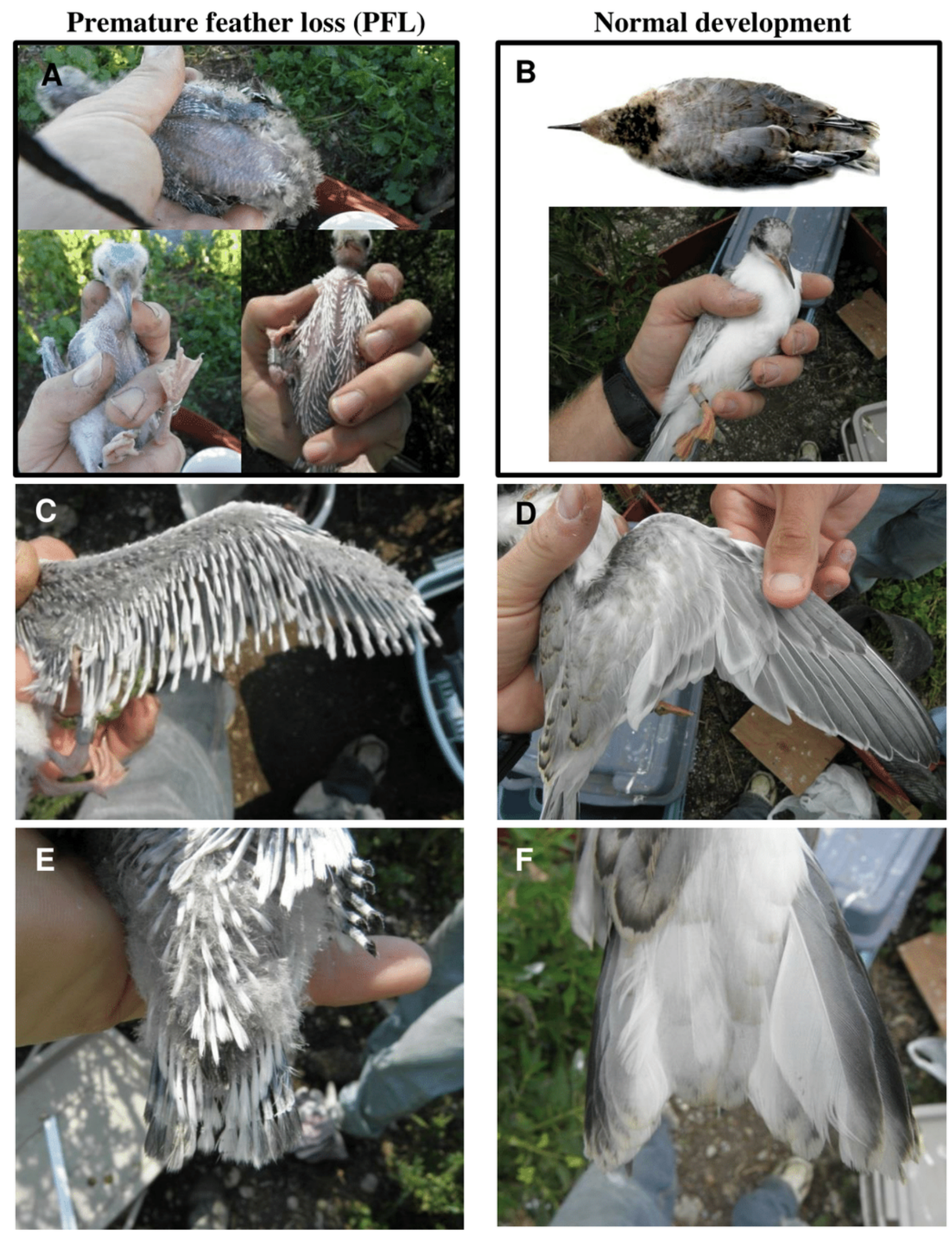
2

Growth in mass of the eight chicks exhibiting premature feather loss.

Figure 2. Growth in mass of the eight chicks exhibiting premature feather loss [PFL] (black lines $=95 \%$ confidence intervals) superimposed over the range of mass development for normal chicks in 2014 ( $n=159$ chicks, grey shading = area between 95\% confidence intervals). For PFL chicks measured later in development ( $>30 \mathrm{~d}$ of age), when fewer measurements were available, individual data points are plotted.

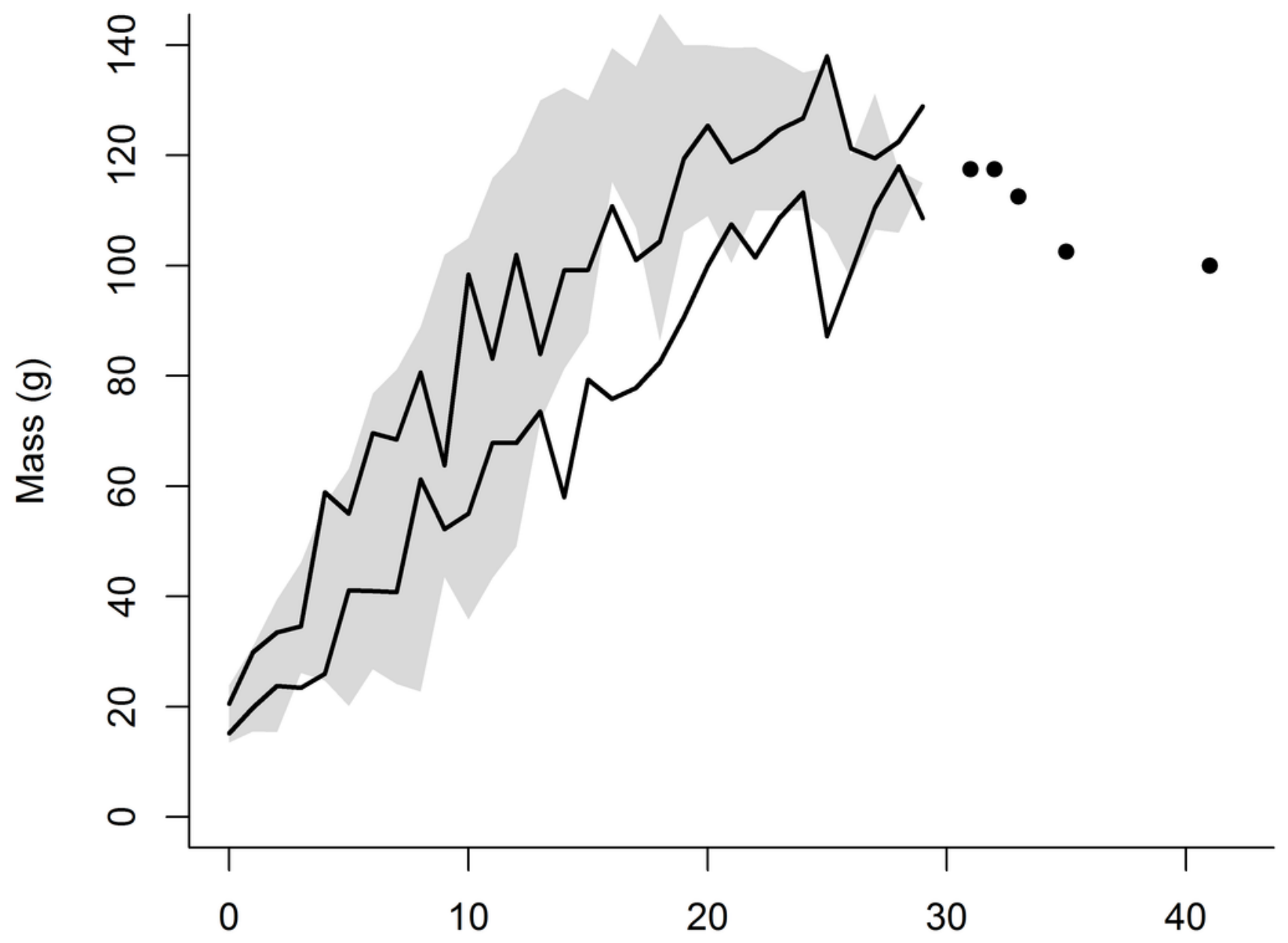




\section{3}

Changes in mean daily weather conditions relative to hatching and exhibiting premature feather loss.

Figure 3. Changes in mean daily weather conditions, (a) near-shore lake surface temperature, (b) air temperature, (c) wind speed, and (d) wind direction (maximum gust), and correspondence with distribution of hatching dates (blue boxplots and outlier) and dates of first exhibiting premature feather loss [PFL] (green boxplots and outlier). Trend lines are 7day running average of the weather variable. Grey shading highlights the period of plummeting near-shore surface water temperatures (2 -10 July).

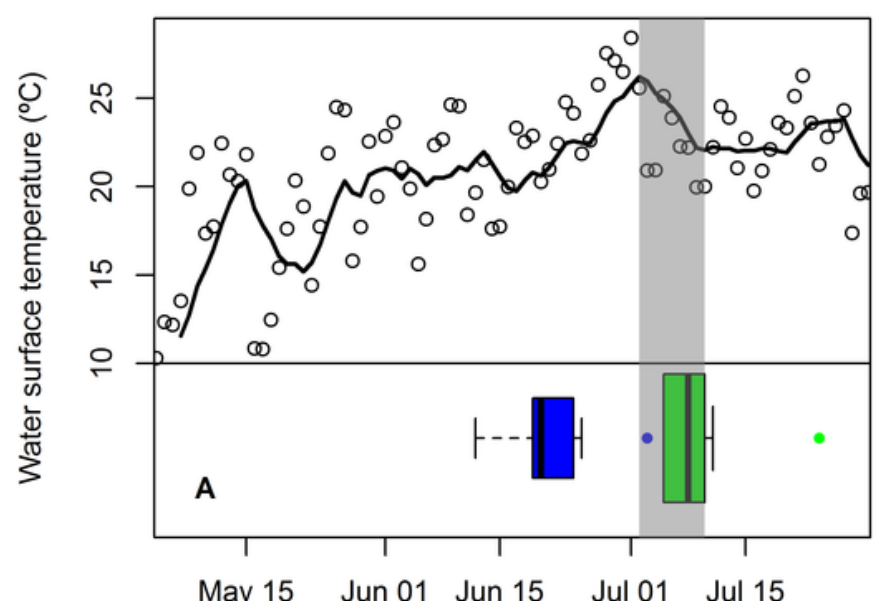

May 15 Jun 01 Jun 15 Jul 01 Jul 15

Date

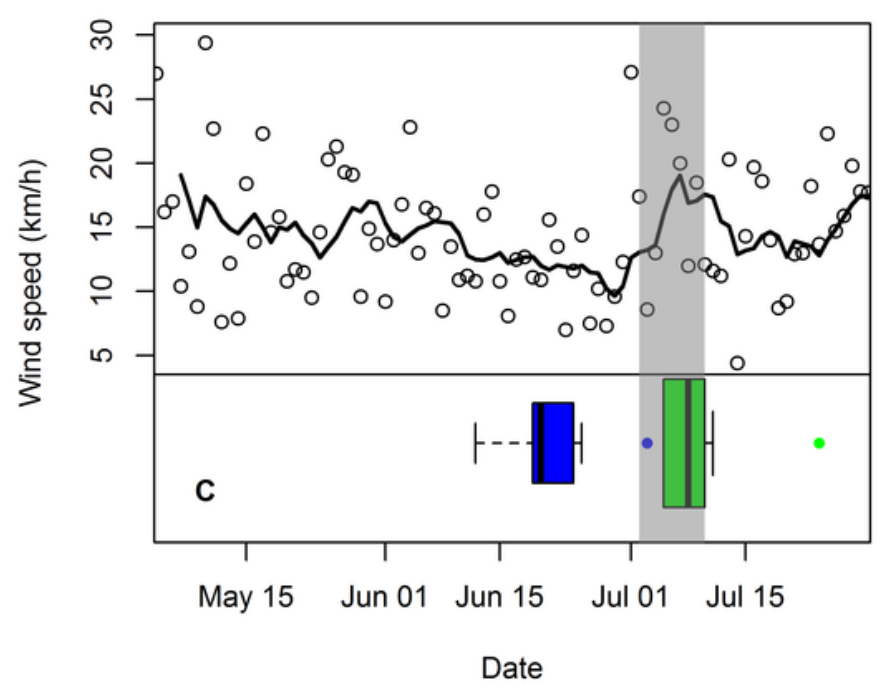

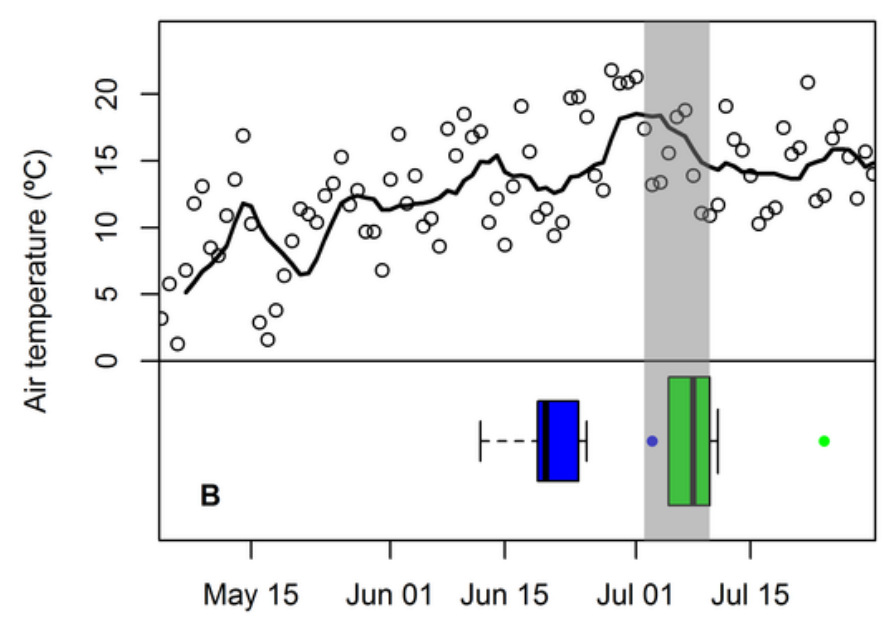

Date

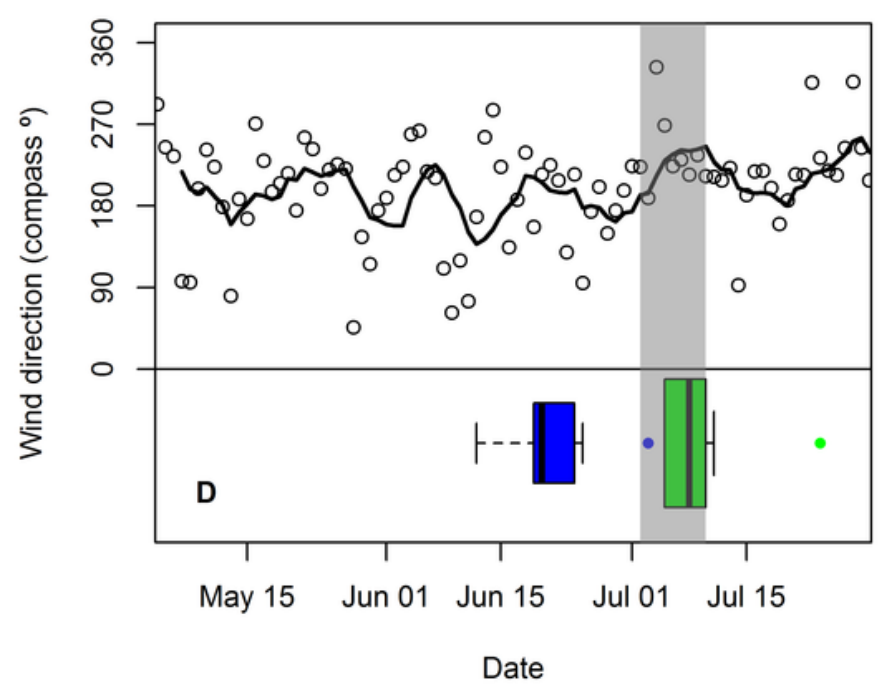

